Psychological well-being and social media users' behavioral online patterns in everyday life and during COVID-19 pandemic

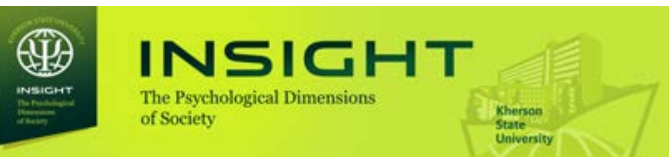

DOI: $10.32999 / 2663-970 X / 2021-5-9$

Link article (Style APA): Hudimova A. Kh. (2021). Psychological well-being and social media users' behavioral online patterns in everyday life and during COVID-19 pandemic. Insight: the psychological dimensions of society, 5, 133-147. DOI: 10.32999/2663-970X/2021-5-9

Link article (Style DSTU 8302: 2015): Hudimova A. Kh. Psychological well-being and social media users' behavioral online patterns in everyday life and during COVID-19 pandemic. Insight: the psychological dimensions of society, 2021, 5, 133-147. DOI: 10.32999/2663-970X/2021-5-9

UDC 159.9.019.4:316.472.4

\title{
Psychological well-being and social media users' behavioral online patterns in everyday life and during COVID-19 pandemic
}

\author{
Психологічне благополуччя та патерни онлайн-поведінки \\ користувачів соціальних мереж у повсякденності \\ та під час пандемії COVID-19
}

Received: March 15, 2021

Hudimova Alisar Khaliedivna

PhD Candidate in Psychology of

Department Practical and Clinical Psychology

Odesa I. I. Mechnikov National University, Ukraine

alisarhudimova@onu.edu.ua

ORCID 0000-0001-9996-0674
Accepted: May 25, 2021

\author{
Гудімова Алісар Халєдівна \\ аспірантка кафедри практичної \\ та клінічної психології \\ Одеський національний університет \\ імені I. I. Мечникова, Україна \\ alisar.hudimova@onu.edu.ua \\ ORCID 0000-0001-9996-0674
}

\begin{abstract}
Social media is an integral part of everyone's life, meeting the needs of belonging and relaxation. During the progression of the COVID-19 pandemic, the need for socialization increases, as a result of which the degree of user involvement increases. The purpose of the research was to theoretically substantiate the results of an empirical study of the relationship between the social media use and the psychological well-being of users ( $\mathrm{N}=516)$ in everyday life and during a global pandemic. Methods: standardized valid psychodiagnostic methods, author's questionnaire, correlation and factor analyzes. Results: The research allowed to establish the following individual characteristics of the behavior of young users in social media in different life circumstances. One of the research hypotheses was the assumption that by limiting the ability to communicate and meet with friends
\end{abstract}

\begin{abstract}
Анотація
Соціальні мережі $є$ невід'ємною складовою життя кожної людини, забезпечуючи задоволення потреб у приналежності та релаксації. У період прогресування пандемії COVID-19 необхідність у соціалізації зростає, внаслідок чого підвищується ступінь залученості користувачів. Мета: теоретично обгрунтувати отримані результати емпіричного дослідження зв'язку типу використання соцмереж з психологічним благополуччям користувачів $(\mathrm{N}=516)$ у звичайному житті та в умовах всесвітньої пандемії. Методи: стандартизовані валідні психодіагностичні методики, авторська анкета, кореляційний та факторний аналізи. Результати: Проведене дослідження дозволило встановити наступні індивідуальні особливості поведінки юних користувачів у соціальних мережах у різних життєвих обставинах. Однією з дослідницьких гіпотез було
\end{abstract}


and relatives during self-isolation, the share of virtual communication will increase. During quarantine, young people, as in everyday life, prefer to watch a variety of videos and read posts, i.e. passive use, rather than communication. Spending time on various social media applications is a kind of coping strategy, which becomes a trigger for the formation of social media disorder. Due to the uncontrolled social media use during the period of self-isolation, young people face changes in sleep, mostly dysomnia. Excessive involvement in the social media increases during quarantine, leading to insomnia. Paired correlation coefficients of the subjects' complaints about "Negative changes in sleep" have 16 highly reliable relationships in the range from $r=.156$ to $r=.444$ or $\rho \leq .015-.0000$. Conclusions: The lack of hygienic and controlled spending time on social media in everyday life and during self-isolation provokes an exacerbation of anxiety, apathy, depressed mood and a sense of isolation from society. The desire of young people to endure forced isolation without negative experiences leads to excessive online involvement.

Key words: psychological well-being, passive use of social media, social media disorder, COVID-19, behavioral patterns, mental health, isolation.

\section{Introduction}

The relevance of the research is due to the development of modern technologies, including gadgets, thanks to which people are constantly online. As a result, the share of virtual communication in the total amount of social interactions of the individual is growing.

This issue has not been studied sufficiently in both domestic and foreign works of scientists. The situation is constantly changing, so its assessment is always relevant.

As a result of the analysis of the scientific literature, it was found that external factors (distance of interlocutors, asymmetry of contact, etc.) tend to mask the psy chological characteristics of the social media users, as well as to compensate for communication barriers. The most active users are the younger generation aged 15 to 28 years. There are enough studies that reveal the negative consequences of virtual communication, such as Internet addiction, autism, gambling, and inadequate effects in the process of social perception. Several studies demonstrate the negative association between using Facebook and psychological припущення, що через обмеження можливості спілкуватися та зустрічатися з друзями та близькими у період самоізоляції, збільшиться частка віртуальної комунікації. За час карантину юнаки, як і в звичайному житті, віддають перевагу перегляду різноманітних відео-роликів та читанню постів, тобто пасивному використанню, ніж спілкуванню. Проведення часу за різними додатками соцмереж $€$ своєрідною копінг-стратегією, що стає тригером формування соціально-мережевого розладу. Внаслідок неконтрольованого використання соцмереж в період самоізоляції юнаки наражаються на зміни сну, переважно дисомнію. Під час карантину надмірна залученість у соцмережі збільшується, призводячи до безсоння. Парні коефіцієнти кореляції скарг досліджуваних на "Негативні зміни сну" мають 16 високо достовірних зв'язків у діапазоні від $r=.156$ до $r=.444$ або $\rho \leq .015-.0000$. Висновки: Відсутність гігієнічного та контрольованого проведення часу у соцмережаху звичайному житті та під час самоізоляції провокує загострення тривоги, апатії, пригніченого настрою та відчуття відірваності від соціуму. Прагнення юнаків перенести вимушену ізоляцію без негативних переживань призводить до надмірної онлайн-залученості.

Ключові слова: психологічне благополуччя, пасивне використання соцмереж, соцмережевий розлад, психічне здоров'я, ізоляція.

\section{Вступ}

Актуальність дослідження зумовлена розвитком сучасних технологій, зокрема гаджетів, завдяки яким людина постійно знаходиться онлайн. Внаслідок чого зростає частка віртуальної комунікації у загальному обсязі соціальних взаємодій індивіда.

Дане питання не вивчено в достатньому обсязі як у вітчизняних, так і у зарубіжних працях вчених. Ситуація постійно змінюється, тому ̈ㅣ оцінка завжди представляється актуальною.

У результаті проведеного аналізу наукової літератури було встановлено, що зовнішні чинники (віддаленість співрозмовників, несимультанність контакту і т.п.) схильні маскувати психологічні особливості користувачів соціальних мереж, а також компенсувати комунікативні бар'єри. Найбільш активними користувачами є молоде покоління у віці від 15 до 28 років. Існує достатньо досліджень, що відкривають негативні наслідки віртуального

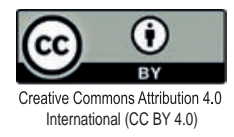


Psychological well-being and social media users' behavioral online patterns in everyday life and during COVID-19 pandemic

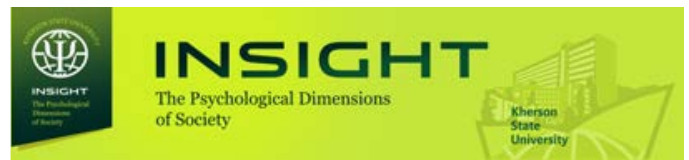

well-being (Shakya \& Christakis, 2017; Verduyn et al., 2017). Many researchers have also found negative associations between social media usage and various indicators of mental health, particularly among adolescents and young people. It is known that some young users with self-esteem problems and lack of stable contacts in life, create accounts of fictional people, hide their age, gender, and any other aspect of identity. In this way, they get the opportunity to escape from the "real" society and the opportunity to express themselves in cyberspace, where they can enlist the support of like-minded people. This behavior helps to get rid of loneliness but does not solve the problem.

Social media use among adolescents is associated with fear of missing out, loneliness, hyperactivity, anxiety, and depression (Barry, Sidoti, Briggs, Reiter, and Lindsey, 2017). The concept of "fear of missing out" is new but is spreading rapidly in foreign science due to the growing popularity of social media. This term is used to describe a state of concern that social events occur without the participation of the user. As a result, a person feels the need to constantly monitor what others are doing. This phenomenon is associated with low mood and decreased life satisfaction.

The number of accounts also has a direct impact on the psychological well-being of users. Thus, researchers have found that compared to people who use 0 -2 social media platforms, people who use 7-11 platforms are significantly more likely to have increased levels of depression and anxiety symptoms (Primack etal., 2017). Studies show that active young users who spend more than 2 hours on social media are more likely to complain of mental health, including psychological disorders: anxiety and depression (Hugues \& Rosamund, 2015). The positive relationship between social media use and psychological well-being is usually explained by social support. While a negative connection combines user behavior that does not help meet acceptance needs and community affiliation. Active use includes any activity on social media that promotes direct exchange with others, such as direct communication. Passive use involves tracking other people's lives without direct involvement, such as scrolling through profiles, images, videos, or updates. Although the results спілкування, такі як: інтернет адикція, аутизація, гемблінг, неадекватні ефекти в процесі соціальної перцепції. Ряд досліджень демонструє негативний зв'язок використання Facebook 3 психологічним благополуччям (Shakya \& Christakis, 2017; Verduyn et al., 2017). Багато дослідників також встановили негативні асоціації використання соціальних мереж 3 різними показниками психічного здоров'я, зокрема серед підлітків та молодих людей. Відомо, що деякі юні користувачі з проблемами самооцінки та відсутністю стійких контактів у житті, створюють акаунти вигаданих осіб, приховують власний вік, стать та будь-який інший аспект ідентичності. Таким чином вони отримують можливість втечі від “реального” суспільства та можливість проявляти себе у віртуальному просторі, де можуть заручитися підтримкою однодумців. Така поведінка допомагає позбавитися відчуття самотності, але не вирішує актуальної проблеми.

Використання соціальних мереж серед підлітків пов'язано зі страхом щось упустити (fear of missing out), самотністю, гіперактивністю, тривогою та депресією (Barry, Sidoti, Briggs, Reiter, and Lindsey, 2017). Поняття “страх щось упустити" є новим, але швидко розповсюджується у зарубіжній науці у зв'язку зі збільшенням популярності соціальних мереж. Цей термін використовують для опису стану занепокоєння, що соціальні події відбуваються без участі користувача. Внаслідок чого людина відчуває необхідність постійно слідкувати за тим, що роблять інші. Даний феномен асоціюється з низьким настроєм та зниженням задоволеності життям.

Кількість акаунтів також має безпосередній вплив на психологічне благополуччя користувачів. Отже, дослідниками було встановлено, що порівняно з особами, які використовують 0-2 платформи соціальних мереж, у осіб, які використовують 7-11 платформ, значно більша ймовірність підвищеного рівня депресії та симптомів тривоги (Primack et al., 2017). Дослідження показують: активні юні користувачі, що проводять більше 2-х годин у соцмережах, частіше скаржаться на психічне здоров'я, включаючи психологічні 
are based primarily on cross-sectional studies, they indicate that active use is associated with greater psychological well-being and passive use is associated with less (Verduyn et al., 2017). It is likely that people who are more involved in social media feel positive, more supported, and socially connected, which can protect them from increased anxiety and depression. In contrast, taking into account that passive use consists mainly of scrolling and reviewing other people's lives, it can provide a platform for social comparisons and envy, which in turn can put people at increased risk for anxiety and depression (Seabrook et al., 2016).

It is important to study the relationship between online spending and users' psychological well-being during the global COVID-19 pandemic. On the one hand, social media are one of the main and safe means of communication with friends and family, which can be a source of social support. On the other hand, pandemic research has linked the overuse of social media to low levels of psychological well-being. Social media use during a global pandemic has a significant impact on the psychological well-being of people, especially the younger generation. The huge amount of information about COVID-19 that is generated on social media has a significant burden on users and a strong impact on their psychological well-being (Islam et al., 2020). The most common manifestations of decreased psychological well-being are signs of depression (Ivie, et al. 2020), risky behavior (Vannucci, et al., 2020), and self-image disorders (Saiphoo \& Vahedi, 2019). The researchers found that increasing feelings of loneliness and isolation involved high levels of anxiety and overuse of social media, which could be a strategy to overcome feelings of loneliness. However, in some cases, this may be a maladaptive strategy that heightens the anxiety of single people in the specific circumstances of a pandemic (Boursier, et al., 2020).

Thus, the study of social media's impact on the psychological well-being of young users before and during the progression of the COVID-19 pandemic is relevant and extremely important.

Hypothesis. Prolonged time spent on social media and type of activity lead to psychological disorders, including sleep disorders, anxiety, розлади: прояви тривоги та депресії (Hugues \& Rosamund, 2015). Позитивний зв'язок між використанням соціальних мереж та психологічним благополуччям, як правило, пояснюється соціальною підтримкою. У той час, як негативний зв'язок поєднує поведінку користувачів, що не допомагає задовольнити потреби у прийнятті та приналежності до спільноти. Активне використання включає будь-яку діяльність у соцмережах, яка сприяє безпосередньому обміну з іншими, наприклад, пряме спілкування. Пасивне використання включає відстеження життя інших людей без безпосереднього залучення, наприклад, прокручування профілів, зображень, відео або оновлень. Незважаючи на те, що результати засновані переважно на дослідженнях поперечного перерізу, вони вказують, що активне використання асоціюється з більшим психологічним благополуччям, а пасивне - 3 меншим (Verduyn et al., 2017). Цілком ймовірно, що люди, які активніше беруть участь у соціальних мережах, почуваються позитивно, більш підтриманими та соціально зв'язаними, що може захистити їх від підвищення тривоги та депресії. На відміну від цього, враховуючи, що пасивне використання складається в основному з прокрутки та перегляду життя інших людей, це може забезпечити платформу для соціальних порівнянь та заздрості, що, відповідно, може поставити людей у підвищений ризик тривоги та депресії (Seabrook et al., 2016).

Важливим $є$ питання вивчення зв'язку проведення часу онлайн та психологічного благополуччя користувачів під час всесвітньої пандемії COVID-19. 3 одного боку, соціальні мережі $\epsilon$ одним із головних та безпечних засобів спілкування 3 друзями та родиною, що може стати джерелом соціальної підтримки. 3 іншого боку, дослідження до пандемії встановили зв'язок між надмірним використанням соціальних мереж та низьким рівнем психологічного благополуччя. Використання соціальних мереж під час всесвітньої пандемії значно впливає на психологічне благополуччя людей, особливо на молоде покоління. Величезна кількість інформації про COVID-19, яка генерується в соціальних мережах, має значне

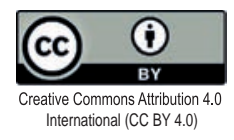


Psychological well-being and social media users' behavioral online patterns in everyday life and during COVID-19 pandemic

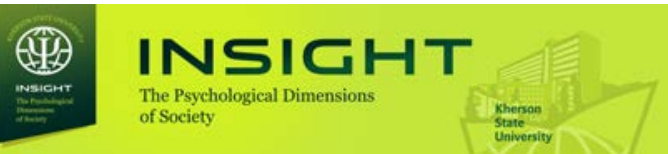

and depression, in everyday life and during the COVID-19 pandemic.

The purpose is an empirical research of behavioral patterns of social media users and their psychological well-being in everyday life and during the progression of COVID-19.

\section{Methodology}

The program of this study consisted of the clinical and psychological method, content analysis, as well as diagnostic techniques. An empirical research of the relationship between changes in mental health due to social media use was conducted in several stages. At the first stage, the research problem was developed, hypotheses were formed, psychodiagnostic tools and research contingent were selected. The second stage involved the collection of empirical data to determine the specifics of social media's impact on the users' psychological state. Respondents were interviewed to learn more about their attitudes toward social media. According to the selected methods, individual features and patterns of users that have a direct impact on the nature of the use of social networking applications and spending time online have been established. At this stage, the results of research work were analyzed and processed using the methods of mathematical statistics according to the consistency of the psychodiagnostic techniques used. The third stage was to establish the features of the users' psychological well-being and the use of social media in conditions of forced self-isolation.

Participants. The research involved young people $(\mathrm{N}=516)$ aged from 15 to 21 years. Representatives of this age group are the most active users of various social networking applications. The average age of the sample was 17 years $(M=17.92, S D=3.003)$. The sample size was determined by the number of participants who filled in the questionnaires correctly and completely.

Procedure and instruments. Participants were invited to participate in the research through information on educational sites. The participants were informed that the research would be anonymous and conducted to study the social media's impact on the psychological state of their age group. All participants stated that they understood навантаження на користувачів та сильний вплив на їх психологічне благополуччя (Islam et al., 2020). Найбільш поширеними проявами зниження психологічного благополуччя $\epsilon$ : ознаки депресії (Ivie, et al. 2020), ризикованої поведінки (Vannucci, et al., 2020) та порушення іміджу власного тіла (Saiphoo \& Vahedi, 2019). Дослідники встановили, що посилення почуття самотності та ізоляції передбачало високий рівень тривожності та надмірного використання соціальних мереж, що може виступати стратегією подолання почуття самотності. Однак, у деяких випадках це може представляти неадаптивну стратегію, що підсилює тривогу самотніх людей у конкретних обставинах пандемії (Boursier, et al., 2020).

Таким чином, дослідження впливу соцмереж на психологічне благополуччя користувачів юнацького віку до та під час прогресування пандемії COVID-19 є актуальним та вкрай важливим.

Гіпотеза. Тривале перебування у соцмережах та тип активності призводить до психологічних розладів, зокрема порушення сну, тривожності та депресії, у повсякденності та протягом пандемії COVID-19

Мета: емпіричне дослідження поведінкових патернів користувачів соціальних мереж та їх психологічного благополуччя у повсякденності та при прогресуванні COVID-19.

\section{Методологія}

Програму даного дослідження склали: клініко-психологічний метод, контент-аналіз, а також діагностичні методики. Емпіричне дослідження взаємозв'язку змін з боку психологічного здоров'я внаслідок використання соціальних мереж проводилось у декілька етапів. На першому етапі було розроблено проблему дослідження, сформовані гіпотези, обрано психодіагностичний інструментарій та контингент дослідження. Другий етап передбачав збір емпіричних даних з метою визначити специфіку впливу соціальних мереж на психологічний стан користувачів. Було проведено інтерв'ю $з$ досліджуваними для більш детального вивчення їх відношення до соціальних мереж. Відповідно до обраних методик були встановлені індивідуальні

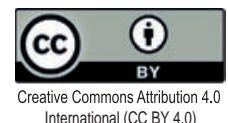


the risks and wanted to participate in the research. The test time was unlimited, but the average duration was 30 minutes. The research was conducted in a form convenient for participants, either paper or computer version. During the pandemic, the research was conducted exclusively online.

The research procedure consisted of filling in the questionnaire by the respondents. Each questionnaire was accompanied by instructions indicating aspects of the research: confidentiality, purpose, and time. A specially designed questionnaire was used to collect data on the socio-demographic characteristics of the subjects. FPI - form B, $\alpha=.81$ (Fahrenberg, Hampel \& Selg, 2010), Warwick-Edinburgh Mental Well-being Scale, $\alpha=.85$ (WEMWBS) (Tennant et al., 2007), a Questionnaire to determine the severity and type of loneliness, $\alpha=.77$ (Korchagina, 2008); Social Media Disorder Scale (Eijnden, et al., 2016) were used to study the psychological and individual spheres. For the study of 202 participants, a version with 27 statements of the Social Media Disorder Scale was used, the reliability of which is $\alpha=.85$. This indicates the high reliability of the scale. At the stage of studying the peculiarities of the social media use during the quarantine period, 254 participants were interviewed in a short version $(\alpha=.82)$. Questionnaires consisted of multiple options, rating scales (eg. Likert scale), and general questions. In addition, to assess the participants' condition due to forced self-isolation during COVID-19 were introduced such issues as: "Increased online communication", "Behavior changes", "Feelings of quarantine", "Frequency of fear associated with coronavirus", "Frequency of social media use for distraction", "Sleep changes". To obtain data on family relationships, to estimate the amount of time spent on social media, a specially designed questionnaire was developed and implemented.

\section{Data analysis}

Mathematical analysis of empirical data was performed using statistical software packages IBM SPSS Statistics 23.0.0. This research presents correlation analysis, Student's t-test, Pearson's correlation coefficient ( $r$ ), factor analysis. особливості та патерни користувачів, які мають безпосередній вплив на характер користування додатками соцмереж та проведення часу онлайн. На даному етапі були проаналізовані та опрацьовані результати дослідницької роботи за допомогою методів математичної статистики за узгодженістю використаних психодіагностичних інструментів. Третій етап полягав у встановленні особливостей психологічного благополуччя користувачів та використання соціальних мереж в умовах вимушеної самоізоляції.

\section{Учасники}

У дослідженні брали участь молоді люди (N = 516) у віці від 15 до 21 року. Представники цієї вікової групи $\epsilon$ найактивнішими користувачами різних додатків соціальних мереж. Середній вік вибірки становив 17 років (M = 17.92, SD = 3.003). Обсяг вибірки визначався кількістю учасників, які правильно та повністю заповнили анкети.

\section{Процедура та інструменти}

Учасникам було запропоновано взяти участь у дослідженні шляхом інформації на освітніх сайтах. Досліджуваним було надано інформацію про те, що дослідження буде анонімним та проведено для вивчення впливу соціальних мереж на психологічний стан їх вікової групи. Усі учасники зазначили, що розуміють ризики та бажають взяти участь у дослідженні. Час випробування був необмежений, але середній час проходження становив 30 хвилин. Дослідження проводилось у формі зручній для учасників, або паперовій, або комп'ютерній версії. Протягом пандемії дослідження проводилося виключно в онлайн формі.

Процедура дослідження полягала в заповненні анкети респондентами. Кожна анкета супроводжувалась інструкцією із зазначенням аспектів дослідження: конфіденційності, мети та часу. Для збору даних: про соціально-демографічні характеристики досліджуваних був використаний спеціально розроблений опитувальник; FPI - форма В, $\alpha=.81$ (Fahrenberg, Hampel \& Selg, 2010), шкала психологічного благополуччя Варвік-Едінбург, $\alpha=.85$ (WEMWBS) (Tennant et al., 2007), опитувальник для визначення тяжкості та типу

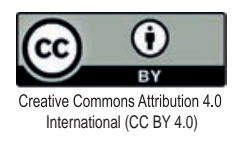


Psychological well-being and social media users' behavioral online patterns in everyday life and during COVID-19 pandemic самотності, $\alpha=.77$ (Корчагіна, 2008); шкала соцмережевого розладу (Eijnden, et al., 2016) були використані для вивчення психологічної та індивідуальної сфер. Для дослідження 202 учасників була застосована версія шкали соцмережевого розладу з 27 твердженнями, надійність за внутрішньою узгодженістю якої $\alpha=.85$, що свідчить про високу надійність шкали. На етапі дослідження особливостей використання соцмереж на період карантину 254 досліджуваних проходили скорочену версію $(\alpha=.82)$. Анкети складались із множинних варіантів, шкал оцінок (наприклад, шкала Лайкерта) та закритих питань. Крім того, для оцінки стану досліджуваних внаслідок вимушеної самоізоляції під час COVID-19 були введені такі питання, як: “Збільшення спілкування онлайн”, “Зміна поведінки”, “Почуття у зв'язку з карантином”, “Частота страху, пов’язаного з коронавірусом”, “Частота використання соціальних мереж для відволікання уваги”, “Зміни сну”. Для отримання даних про сімейні стосунки, для оцінки кількості часу, проведеного в соціальних мережах була розроблена та впроваджена спеціально розроблена анкета.

\section{Аналіз даних}

Математичний аналіз емпіричних даних здійснювався за допомогою статистичних програмних пакетів IBM SPSS Statistics 23.0.0.

Table 1. Comparative table of leading activities in social media

Таблиця 1. Порівняльна таблиця провідної діяльності у соціальних мережах

\begin{tabular}{|c|c|c|c|c|c|}
\hline $\begin{array}{l}\text { Indicators } \\
\text { Показники }\end{array}$ & $\begin{array}{c}\text { Leading social } \\
\text { media activity } \\
\text { Провідна діяль- } \\
\text { ність у СМ } \\
\end{array}$ & $\mathbf{M}$ & \pm 6 & $\pm m$ & $\begin{array}{c}\text { t- Student, } \rho \\
\text { t- Стьюдента, } \rho\end{array}$ \\
\hline \multirow{2}{*}{$\begin{array}{c}\text { Escape from problems in social media } \\
\text { Втеча від проблем у CM }\end{array}$} & 1 & 2.20 & .955 & .118 & -3.5 \\
\hline & 3 & 2.78 & 1.001 & .115 & .001 \\
\hline \multirow{2}{*}{$\begin{array}{c}\text { Loneliness } \\
\text { Стан самотності }\end{array}$} & 1 & 6.84 & 3.148 & .394 & 3.3 \\
\hline & 3 & 8.47 & 2.759 & .316 & .002 \\
\hline \multirow{2}{*}{$\begin{array}{c}\text { Problematic social media use } \\
\text { Проблематичне використання }\end{array}$} & 1 & 7.42 & 2.301 & .288 & -2.13 \\
\hline & 3 & 8.30 & 2.519 & .289 & .03 \\
\hline \multirow{2}{*}{$\begin{array}{c}\text { Psychological } \\
\text { Well-being } \\
\text { Психологічне благополуччя }\end{array}$} & 1 & 50.50 & 9.437 & 1.180 & 2.65 \\
\hline & 3 & 46.03 & 10.329 & 1.185 & .008 \\
\hline
\end{tabular}

Note: (SM): 1 - communication; 3 - passive use

Примітка: (CM): 1 - спілкування; 3 - пасивне використання

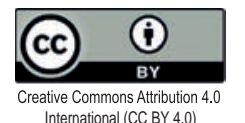


Table 2. The inverse matrix of the components ${ }^{a}$ of the social media users' psychological state Таблиця 2. Обернена матриця компонентіва психологічного стану користувачів соцмереж

\begin{tabular}{|c|c|c|}
\hline \multirow{2}{*}{$\begin{array}{c}\text { Indicators } \\
\text { Показники }\end{array}$} & \multicolumn{2}{|c|}{$\begin{array}{c}\text { Component } \\
\text { Компонент }\end{array}$} \\
\cline { 2 - 3 } & $\mathbf{1}$ & $\mathbf{2}$ \\
\hline $\begin{array}{c}\text { Depression } \\
\text { Депресивність }\end{array}$ & .875 & \\
\hline $\begin{array}{c}\text { Emotional lability } \\
\text { Емоційна лабільність }\end{array}$ & .860 & \\
\hline $\begin{array}{c}\text { Stress } \\
\text { Рівень стресу }\end{array}$ & .737 & \\
\hline \begin{tabular}{c} 
Psychological Well-being \\
\hline $\begin{array}{c}\text { Психологічне } \\
\text { благополуччя }\end{array}$
\end{tabular} & $\underline{-.652}$ & \\
\hline $\begin{array}{c}\text { Extra / introversion } \\
\text { Екстра-/інтроверсія }\end{array}$ & & .717 \\
\hline $\begin{array}{c}\text { Masculinity - Femininity } \\
\text { Macкулінність } \\
\text { Фемінність }\end{array}$ & $\underline{-.529}$ & $\underline{.572}$ \\
\hline $\begin{array}{c}\text { Length of social media } \\
\text { engagement } \\
\text { Стаж в CM }\end{array}$ & & .563 \\
\hline $\begin{array}{c}\text { Age } \\
\text { Biк }\end{array}$ & & \\
\hline
\end{tabular}

Note. Factors selection method: principal component analysis. Rotation method: Varimax with Kaiser normalization. ${ }^{\text {aThe }}$ rotation converged in three iterations.

Примітка. Метод виділення факторів: метод головних компонент (МГК). Метод обетрання: Варімакс з нормалізацією Кайзера. ${ }^{\text {a } О б е р т а н н я ~ з і и ̆ ш л о с ь ~ з а ~}$ три ітерації.

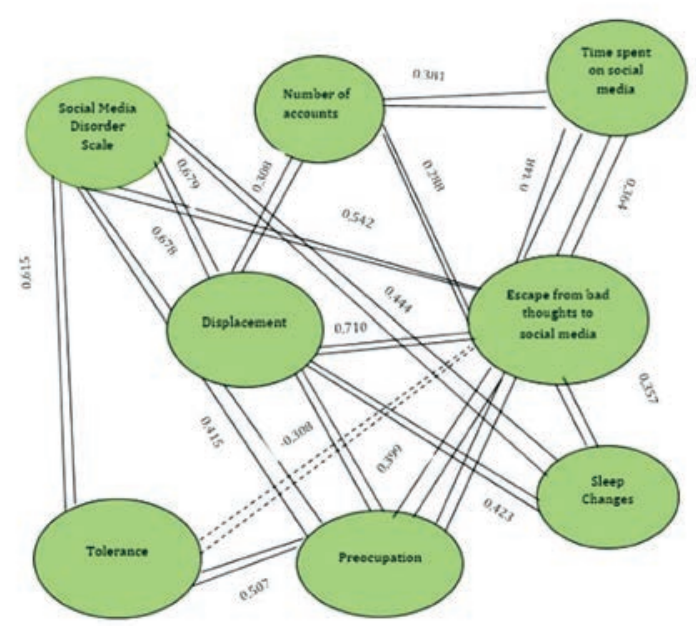

Fig. 1. Correlation pleiad of the number of accounts with the manifestations of social media disorder
У даному дослідженні представленні: кореляційний аналіз, t-критерій Стьюдента, коефіці$є н$ кореляції Пірсона (r), факторний аналіз.

\section{Результати}

Дослідження дозволило встановити психологічні особливості користувачів у залежності від провідної діяльності у соцмережах (табл. 1).

Проведене дослідження дозволяє встановити причинно-наслідкові зв'язки перебування в онлайн-просторі на психологічне благополуччя. Змінюючи патерни спілкування, юнаки змінюють також власну ідентифікацію та намагаються вирішити дилему, яке "Я" у встановленні контакту з іншими є пріоритетним: реальне чи віртуальне (табл. 2).

Метою дослідження було встановити, як змінюється якість взаємодії користувачів з онлайн-середовищем в період пандемії COVID-19. Проаналізувати, чи стають юнаки більш активними у спілкуванні 3 іншими у соцмережах, чи все одно віддають перевагу пасивному проведенню часу.

3 метою більш детальної обробки отриманих даних був застосований факторний аналіз (табл. 3).

Реєстрація у декількох соціальних мережах нерозривно пов'язана 3 постійним відчуттям необхідності перевіряти оновлення у кожній з них, прагенням поскролити стрічку з метою відволіктися та розслабитися. Вказані патерни поведінки призводять не лише до збільшення часу

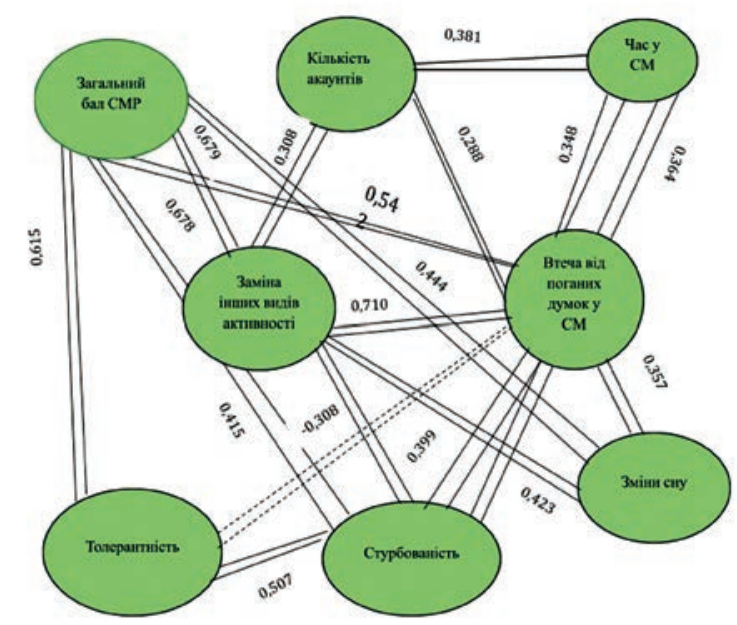

Рис. 1. Кореляційна плеяда зв'язку кількості акаунтів з проявами соцмережевого розладу 
Psychological well-being and social media users' behavioral online patterns in everyday life and during COVID-19 pandemic

Table 3. Inverse matrix of components ${ }^{\mathrm{a}}$ after rotation of social media users' indicators during the period of self-isolation

Таблиця 3. Обернена матриця компонентіва після обертання показників користувачів соцмереж на період самоізоляції

\begin{tabular}{|c|c|c|}
\hline \multirow{2}{*}{$\begin{array}{l}\text { Indicators } \\
\text { Показники }\end{array}$} & \multicolumn{2}{|c|}{$\begin{array}{l}\text { Component } \\
\text { Компонент }\end{array}$} \\
\hline & 1 & 2 \\
\hline $\begin{array}{c}\text { Social Media Disorder Scale } \\
\text { Шкала соцмережевого розладу }\end{array}$ & .839 & \\
\hline $\begin{array}{c}\text { Conflict } \\
\text { Конфліктність }\end{array}$ & .815 & \\
\hline $\begin{array}{c}\text { Problems } \\
\text { Проблематичне використання CM }\end{array}$ & .806 & \\
\hline $\begin{array}{c}\text { Persistence } \\
\text { Наполегливе використання СМ }\end{array}$ & .657 & \\
\hline $\begin{array}{l}\text { Fear of coronavirus } \\
\text { Страх через коронавірус }\end{array}$ & .438 & \\
\hline $\begin{array}{c}\text { Feeling due to quarantine } \\
\text { Самопочуття у зв'язку з карантином }\end{array}$ & & .647 \\
\hline $\begin{array}{c}\text { Displacement } \\
\text { Заміна інших видів активності }\end{array}$ & .447 & .644 \\
\hline $\begin{array}{c}\text { Depth of loneliness } \\
\text { Глибина переживання стану самотності }\end{array}$ & & .610 \\
\hline $\begin{array}{l}\text { Sleep changes } \\
\text { Зміни сну }\end{array}$ & & .598 \\
\hline $\begin{array}{c}\text { Number of social media accounts } \\
\text { Кількість акаунтів }\end{array}$ & & .569 \\
\hline $\begin{array}{l}\text { Psychological Well-being } \\
\text { Шкала благополуччя }\end{array}$ & & -.521 \\
\hline $\begin{array}{c}\text { Length of social media engagement } \\
\text { Стаж у СM }\end{array}$ & & .451 \\
\hline
\end{tabular}

Note. Inversion method: varimax with Kaiser normalization. ${ }^{\text {aThe }}$ rotation converged in three iterations (orthogonal).

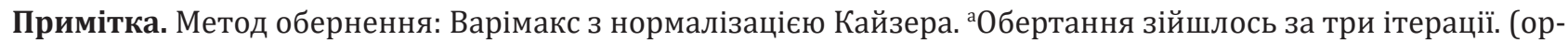
тогональне).

As a result of the research, it was established that registration in 2-3 social media can cause the development of social media disorder.

\section{Discussion}

The study provides additional information on social media's impact on psychological wellbeing both in everyday life and in the context of the progression of the COVID-19 pandemic.

It has been established that in everyday life when discussing their experiences, young people live them and can find solutions. Modern young people communicate online with family members, close friends, and fellow students, avoiding new acquaintances. In case of problems, users who онлайн, але й стають тригерами розвитку початкових проявів соцмережевого розладу (рис. 1).

У результаті дослідження вдалося встановити, що зареєстрованість у 2-3-х соціальних мережах може стати причиною розвитку соціально-мережевого розладу.

\section{Дискусія}

Проведене дослідження надає додаткову інформацію про вплив соціальних мереж на психологічне благополуччя як у звичайному житті, так і в умовах прогресування пандемії COVID-19.

Встановлено, що у повсякденності, обговорюючи свої переживання, юнаки їx 
have encountered similar difficulties may ask for help or advice anonymously on the forums. Depending on the type of interaction with social media, young people to some extent have a sense of loneliness. Particularly pronounced alienating loneliness with a slight advantage in passive users $(\mathrm{M}=7.29, \pm 6=2.051)$. Due to the involvement in the virtual world, there is a constant mechanism of alienation, which leads to the experience of separation from the world as a whole. Young people begin to feel an inner emptiness, which they try to fill with a variety of interesting content to relieve stress.

There is a tendency among users to shift their attention from negative experiences to social media, due to which misunderstandings with a close environment periodically arise. Despite the latter, young people do not replace various forms of leisure and education on social media. However, it should be noted that according to the survey, when performing uninteresting activities or homework, most of the time is spent browsing social media. This trend can be explained by the dependence of motivation on the anxiety of young people, which leads to the progression of procrastination (Babatina, Svitenko, 2019).

One study states that the prerequisites for psychological well-being are life satisfaction, independence, optimism (Ma Feng et al., 2020). Young people who prefer to communicate online feel more relaxed, optimistic, confident, and satisfied with the interpersonal contacts $(M=50.50, \pm 6=9.437)$. Thus, the active pattern of spending time on social media leads to increasing the level of psychological well-being. Users who passively spend time on social media are more prone to depression $(\mathrm{M}=6.88, \pm 6=$ 1.774).

The factor analysis allowed to establish the specifics of the psychological state of users in connection with social media use. Thus, 2 factors were identified. The factor "Psychological state" allows us to conclude that the decline in psychological well-being is a consequence of frequent social comparisons of young people themselves and other users, negative perceptions of the quality of online interaction, or problematic social media use. These factors represent cognitive and interactive styles of social media that are проживають та можуть знайти вирішення. Сучасні юнаки спілкуються онлайн з членами родини, близькими друзями та колегами по навчанню, уникаючи нових знайомств. У разі виникнення проблем можуть анонімно на форумах попросити допомоги або поради у користувачів, які зустрічалися з подібними труднощами. В залежності від типу взаємодії з соцмережами у юнаків в тій чи іншій мірі $€$ відчуття самотності. Особливо виражена відчуждаюча самотність 3 незначною перевагою у пасивних користувачів (M = 7.29, $\pm 6=$ 2.051). Через залученість у віртуальний світ постійно діє механізм відчуження, що призводить до переживання відокремленості від світу в цілому. Юнаки починають відчувати внутрішню порожнечу, яку вони намагаються заповнити різноманітним цікавим контентом для зняття напруження.

Серед користувачів визначена тенденція зміщувати увагу з негативних переживань на соціальні мережі, через що періодично виникають непорозуміння з близьким колом спілкування. Не дивлячись на останнє, юнаки не замінюють соціальними мережами різні форми дозвілля та навчання. Однак, необхідно відзначити, що за даними опитування під час виконання нецікавої діяльності або домашніх завдань більшу частину часу займає саме перегляд соціальних мереж. Така тенденція може бути пояснена залежністю мотивації від тривожності юнаків, що призводить до прогресування прокрастинації (Babatina, Svitenko, 2019).

В одному з досліджень вказано, що передумовами психологічного благопоуччя $\epsilon$ задоволеність життям, незалежність, оптимізм (Ма Feng et al., 2020). Юнаки, які віддають перевагу спілкуванню онлайн відчувають себе більш розслабленими, оптимістичними, впевненими та задоволеними у сфері міжособистісних контактів (M = 50.50, \pm 6 = 9.437). Отже, активний патерн проведення часу у соцмереж призводить до збільшення рівня психологічного благополуччя. Користувачі, які пасивно проводять час у соцмережах в більшій мірі схильні до проявів депресивності ( $\mathrm{M}=6.88, \pm 6=1.774)$.

Проведений факторний аналіз дозволив встановити специфіку психологічного

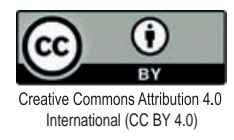


Psychological well-being and social media users' behavioral online patterns in everyday life and during COVID-19 pandemic

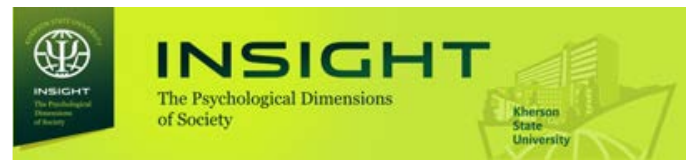

directly related to depression, stress, and anxiety, which can be exacerbated by the constant nature of the social burden online and the difficulty of success among other more popular users. Thus, this article confirms the result of the study, which states that the state of psychological distress is a litmus test that reflects the uncertainty and fear of the impossibility of self-realization (Chkhaidze, Samkova, 2019). The second factor "Social Media Involvement" can be interpreted in such a way that young people become social media users quite early, which imposes on them the "responsibility" to quickly join trends and maintain the image. Young people use social media to quickly and easily establish contacts without additional effort. This ease of contact makes communication much easier for introverted young people. However, social media, like a medal, have two sides. Young people may not realize that social media are quite addictive. This is manifested in the constant checking of smartphones countless times a day, both in his spare time and when doing homework or communicating with others. It can be concluded that by increasing the time on social media, young people increase the risk of problems with their psychological state and health in general. The stress factor is also the pressure of the need to show yourself at your best, to create your own unique and ideal image.

During the pandemic, the share of social media involvement increased significantly, which can be explained as a coping strategy with experiences and the need to feel part of the community. Isolation exacerbates young people's sense of belonging, reflecting a desire to be part of a community in an online social environment (Cheung, Chiu, \& Lee, 2011). The factor analysis shows that users combine the signs of social media disorder with subjective experiences related to the pandemic. The first factor, "Forced Online Involvement," suggests that young people need to disguise their fears by spending too much time online. The second factor "Psychological disharmony" indicates that young people through passive social media use exacerbate feelings of insulation and isolation, disrupt the healthy rhythm of sleep, provoking the consolidation of the bad mood, well-being, and anxiety. The indicator "Replacement of other types of activity" стану користувачів у зв'язку 3 використанням соціальних мереж. Таким чином, було виділено 2 фактори. Фактор “Психологічний стан” дозволяє зробити висновок, що зниження рівня психологічного благополуччя $\epsilon$ наслідком частого соціального порівняння юнаками себе та інших користувачів, негативного сприйняття якості онлайн-взаємодії, або проблематичним використанням соцмереж. Ці чинники представляють пізнавальний та інтерактивний стилі використання соцмереж, які мають прямий зв'язок з депресивністю, переживанням стресу та тривожністю, що можуть бути посилені за рахунок постійного характеру соціального навантаження онлайн та труднощами у досягненні успіху серед інших більш популярних користувачів. Таким чином, у даній статті підтверджений результат дослідження, який констатує, що стан психологічного неблагополуччя $є$ лакмусовою стрічкою, що відображає невпевненість та страх неможливості самореалізації (Чхаідзе, Самкова, 2019). Другий фактор “Залученість у соцмережі" може бути інтерпретований таким чином, що юнаки доволі рано стають користувачами соцмереж, що накладає на них “відповідальність” швидко включатися у тренди та підтримувати імідж. Юнаки використовують соцмережі для швидкого та зручного налагодження контактів без додаткових зусиль. Така легкість установлення контакту значно полегшує спілкування для інтровертованих юнаків. Однак, соцмережі, як медаль, має два боки. Юнаки можуть і не усвідомлювати, що соцмережі є досить адиктивними. Це проявляється у постійній перевірці смартфонів незлічену кількість разів на день як у вільний час, так і при виконанні домашніх завдань чи спілкуванні з іншими. Можна зробити проміжний висновок, що збільшуючи час у соцмережах, юнаки збільшують ризик виникнення проблем з психологічним станом та здоров'ям в цілому. Стресовим чинником також виступає тиск потреби показати себе $з$ найкращої сторони, створити свій унікальний та ідеальний образ.

у період пандемії частка залученості у соціальні мережі зросла в значній мірі, що можна пояснити як копінг-стратегію із

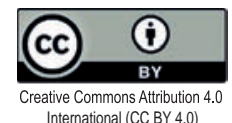


was included in both factors, which demonstrates the ability to procrastinate without guilt due to the slow pace of isolated life, while continuing to monitor changes in social media. Such behavior stimulates an increasing feeling of depression behind the mask of life satisfaction and the absence of risks of interpersonal contacts when using social media, which can provoke sleep disorders, up to insomnia. This research confirmed the results of researchers that the current mental state of man has a significant impact on the regulation of behavior in symbolic space (Khmiliar et al., 2020).

\section{Conclusions}

Social media have both positive and negative features. The nature of users' time in the online environment is of great importance.

It has been established that young people, despite the need to communicate, both in everyday life and during a pandemic, prefer passive social media use, which has its consequences. Firstly, the difficulty of exiting social media ( $M=2.69 ; \mathrm{SD}=.067)$. Secondly, sleep disorders, including insomnia $(\mathrm{M}=2.53$; $\mathrm{SD}=$ .080 ). This can be explained by the phenomenon of so-called "rabbit hole" content on platforms such as TikTok, Instagram, and YouTube. Thirdly, a decrease in the level of psychological well-being. The average result was $\mathrm{M}=47.81, \mathrm{SD}=9.93$. Unsatisfactory levels of psychological well-being are associated with exacerbation of imbalances in the mechanisms of identification and alienation, poor sleep, anxiety, immersion in social media to block negative experiences and avoid new acquaintances.

Young users experience stress and phobias due to the possibility of coronavirus infection, which leads to an increase in social media time to 7 hours or more per day to distract from negative obsessions. During quarantine, despite passive use and isolation, the subjects showed a high level of psychological well-being: $\mathrm{M}=48.66, \mathrm{SD}=8.35$. This trend is since immersion in social media is a kind of coping strategy and a means of supporting the basic mechanisms of socialization. However, due to uncontrolled and prolonged involvement during self-isolation, young users feel more acutely anxiety, apathy, depressed mood, and isolation переживаннями та необхідністю відчувати себе частиною спільноти. Ізоляція загострює у юнаків відчуття приналежності, що відображає прагнення бути частиною спільноти у соціальному середовищі онлайн (Cheung, Chiu, \& Lee, 2011). Проведений факторний аналіз демонструє, що у користувачів поєднуються ознаки соцмережевого розладу з суб'єктивними переживаннями у зв'язку з пандемією. Перший фактор "Вимушена онлайн-залученість” свідчить про необхідність юнаків замаскувати свої страхи під надмірне проведення часу в мережі. Другий фактор "Психологічна дисгармонія” вказує на те, що юнаки через пасивне використання соцмереж загострюють відчуття відокремленості та ізольованості, порушують здоровий ритм сну, провокуючи закріплення поганого настрою, самопочуття та тривожності. Показник "Заміна інших видів активності” увійшов у обидва фактори, що демонструє можливість через повільний ритм ізольованого життя прокрастинувати без відчуття провини, продовжуючи спостерігати за змінами у соціальних мережах. Така поведінка стимулює все більше відчуття пригніченості за маскою задоволеності життям та відсутності ризиків міжособистісних контактів при використанні соціальних мереж, може спровокувати порушення сну, аж до безсоння. У даному дослідженні підтверджено результати дослідників про те, що поточний психічний стан людини має значний вплив на регулювання поведінки у символічному просторі (Khmiliar et al., 2020).

\section{Висновки}

Соціальні мережі мають як позитивні, так і негативні риси. Велике значення має характер проведення часу користувачами в онлайн-середовищі.

Встановлено, що юнаки, не дивлячись на потребу у спілкуванні, як у повсякденності, так і під час пандемії, віддають перевагу пасивному використанню соцмереж, що має свої наслідки. По-перше, труднощі виходу з соцмереж (M = 2.69; SD =.067). По-друге, порушення сну, включаючи безсоння ( $\mathrm{M}=2.53$; $\mathrm{SD}=.080)$. Це може бути пояснено феноменом так званої “кролячої нори” контенту на таких платформах

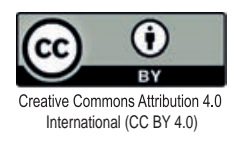


Psychological well-being and social media users' behavioral online patterns in everyday life and during COVID-19 pandemic

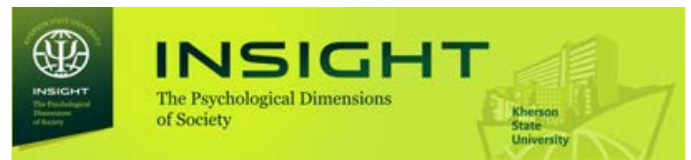

from society. Not the last role in such a condition is played by the neglect of a normal sleep.

Thus, young users through an obsessive pattern of social media use or procrastination spend almost all day online. It often provokes a withdrawal syndrome when trying to distract. The desire of young people to endure forced isolation without negative experiences leads to excessive online involvement.

\section{References}

Babatina, S. I., \& Svitenko, S. V. (2019). Study of adolescents' personal factors of tendency for procrastination. Insight: the psychological dimensions of society. 1.7-14. https://doi.org/10.32999/2663970X/2019-1-1

Barry, C., Sidoti, C., Briggs, S., Reiter, S. \& Lindsey, R. (2017). Adolescent social media use and mental health from adolescent and parent perspectives. Journal of adolescence. 61. 1-11. 10.1016/j.adolescence.2017.08.005.

Boursier, V., Gioia, F., Musetti, A., \& Schimmenti, A. (2020). Facing Loneliness and Anxiety During the COVID-19 Isolation: The Role of Excessive Social Media Use in a Sample of Italian Adults. Frontiers in psychiatry, 11, 586222. https://doi. org/10.3389/fpsyt.2020.586222

Cheung, C., Chiu, P.-Ye. \& Lee, M. (2011). Online Social Networks: Why do Students use Facebook? Computers in Human Behavior, 27, 1337-1343. https:// doi.org/10.1016 / j.chb.2010.07.028

Chkhaidze, A. O., Samkova, O. M. (2019). Peculiarities of Psychological Stability in Youth Age. Insight: the psychological dimensions of society. 1. 51-58. https://doi.org/10.32999/2663-970X/2019-1-8

Eijnden, R., Lemmens, J. \& Valkenburg, P. (2016). The Social Media Disorder Scale: Validity and psychometric properties. Computers in Human Behavior. 61. 478-487. https://doi.org/10.1016/j. chb.2016.03.038.

Fahrenberg, J., Hampel, R. \& Selg, H. (2010). Freiburger Persönlichkeitsinventar (8., erweiterte Aufl.). Göttingen: Hogrefe.

Hugues, S.-K. \& Rosamund, L. (2015). Frequent Use of Social Networking Sites Is Associated with Poor Psychological Functioning Among Children and Adolescents. Cyberpsychology, behavior and social networking. 18. 380-385. 10.1089/ cyber.2015.0055.

Islam, M. A, Barna, S. D, Raihan, H, Khan, M. N. A. \& Hossain, M. T. (2020). Depression and anxiety among university students during the COVID-19 pandemic in Bangladesh: A web-based cross-sectional як TikTok, Instagram та YouTube. По-третє, зниження рівня психологічного благополуччя. Середній результат становив $\mathrm{M}=47.81$, $\mathrm{SD}=9.93$. Незадовільний рівень психологічного благополуччя пов'язаний із загостренням розбалансування діяльності механізмів ідентифікації та відчуження, погіршенням сну, тривожністю, заглибленням у соцмережі для блокування негативних переживань та униканням нових знайомств.

Юні користувачі відчувають напруження та фобії у зв'язку з можливістю зараження коронавірусом, що призводить до збільшення проведення часу у соцмережах до 7 годин та більше на добу з метою відволіктися від негативних нав'язливих думок. Під час карантину, не дивлячись на пасивне використання та ізоляцію, досліджувані продемонстрували високий рівень психологічного благополуччя: $\mathrm{M}=48.66, \mathrm{SD}=8.35$. Така тенденція пов'язана 3 тим, що занурення у соцмережі $є$ своєрідною копінг-стратегією та засобом підтримки елементарних механізмів соціалізації. Однак, через неконтрольовану та тривалу залученість під час самоізоляції юні користувачі гостріше відчувають тривогу, апатію, пригнічений настрій та відірваність від соціуму. Не останню роль у такому стані грає нехтування нормальним режимом сну.

Таким чином, юні користувачі через обсесивний патерн використання соцмереж або через прокрастинацію проводять майже цілий день онлайн, що нерідко провокує синдром відміни при намаганнях відволіктися. Прагнення юнаків перенести вимушену ізоляцію без негативних переживань призводить до надмірної онлайн-залученості.

\section{Список використаних джерел}

Бабатіна C. I., Світенко С. В Вивчення особистісних чинників схильності до прокрастинації осіб юнацького віку. Науковий журнал Інсайт: психологічні виміри суспільства. 2019. 1. С. 7-14. DOI:10.32999/2663-970X/2019-1-1

Корчагина С. Г. Психология одиночества. М.: Московский психолого-социальный институт, 2008. 228 c.

ЧхаідзеА.О.,Самкова О.М.Особливостіпсихологічної стійкості у юнацькому віці. Науковий журнал Інсайт: психологічні виміри суспільства. 2019. 1. C. 51-58. DOI: 10.32999/2663-970X/2019-1-8

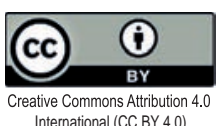


survey. PLoS ONE 15(8): e0238162. https://doi. org/10.1371/journal.pone.0238162

Ivie, E. J., Pettitt, A., Moses, L. J., \& Allen, N. B. (2020). A meta-analysis of the association between adolescent social media use and depressive symptoms. Journal of affective disorders, 275, 165-174. https://doi.org/10.1016/j.jad.2020.06.014

Khmiliar, O., Popovych, I., Hrys, A., Pavliuk, M., Zavatska, N., Lytvynenko, O., \& Blynova, O. (2020). Spatial Regulation of Personality Behavior in the Conditions of Progression of the COVID-19 Pandemic. Revista Inclusiones, Vol: 7 num Especial, 289-306. Retrieved from http://www. revistainclusiones.org/index.php/inclu/article/ view/1760

Korchagina, S. G. (2008). The psychology of loneliness: a textbook. Moscow: Moscow Psychological and Social Institute.

Ma, F., Shevchenko, R. P. \& Karhina, N. V. (2020). Student youth representation of psychological well-being: results of content analysis of works. Insight: the psychological dimensions of society, 2020. 3. P. 44-55. DOI: 10.32999/2663-970X/2020-3-3

Primack, B. A., Shensa, A., Sidani, J. E., Whaite, E. O., Lin,L.Y., Rosen, D., Colditz, J. B., Radovic, A., \& Miller,E. (2017). Social Media Use and Perceived Social Isolation Among Young Adults in the U.S. American journal of preventive medicine, 53(1), 1-8. https:// doi.org/10.1016/j.amepre.2017.01.010

Saiphoo, A. N., \& Vahedi, Z. (2019). A meta-analytic review of the relationship between social media use and body image disturbance. Computers in Human Behavior, 101, 259-275. https://doi. org/10.1016/j.chb.2019.07.028

Seabrook, E. M., Kern, M. L., \& Rickard, N. S. (2016). Social networking sites, depression, and anxiety: a systematic review. JMIR mental health, 3(4), e5842.

Shakya, H. B., \& Christakis, N. A. (2017). Association of Facebook Use with Compromised Well-Being: A Longitudinal Study. American journal of epidemiology, 185(3), 203-211. https://doi.org/10.1093/ aje/kww189

Tennant, R., Hiller, L., Fishwick, R., Platt, S., Joseph, S., Weich, S., Parkinson, J., Secker, J., \& Stewart Brown, S. (2007). The Warwick-Edinburgh Mental Well-being Scale (WEMWBS): Development and UK validation. Health and Quality of Life Outcomes, 5, Article 63. https://doi.org/10.1186/1477-75255-63

Vannucci, A., Simpson, E. G., Gagnon, S., \& Ohannessian, C. M. (2020). Social media use and risky behaviors in adolescents: A meta-analysis.
Barry, Christopher \& Sidoti, Chloe \& Briggs, Shanelle \& Reiter, Shari \& Lindsey, Rebecca. Adolescent social media use and mental health from adolescent and parent perspectives. Journal of adolescence. 2017. 61. P. 1-11. DOI: 10.1016/j.adolescence.2017.08.005.

Boursier V., Gioia F., Musetti A., Schimmenti A. Facing Loneliness and Anxiety During the COVID-19 Isolation: The Role of Excessive Social Media Use in a Sample of Italian Adults. Frontiers in Psychiatry. 2020. No. 11. P. 1380

Cheung, Christy \& Chiu, Pui-Yee \& Lee, Matthew. Online Social Networks: Why do Students use Facebook? Computers in Human Behavior. 2011. No. 27. P. 1337-1343. DOI:10.1016 / j.chb.2010.07.028

Eijnden, Regina \& Lemmens, Jeroen \& Valkenburg, Patti. The Social Media Disorder Scale: Validity and psychometric properties. Computers in Human Behavior. 2016. No. 61. P. 478-487. DOI:10.1016/j. chb.2016.03.038

Fahrenberg, J., Hampel, R. \& Selg, H. Freiburger Persönlichkeitsinventar (8., erweiterte Aufl.). Göttingen: Hogrefe, 2010.

Hugues Sampasa-Kanyinga and Rosamund Lewis. Frequent Use of Social Networking Sites Is Associated with Poor Psychological Functioning Among Children and Adolescents. Cyberpsychology, Behavior, and Social Networking. 2015. No. 18(7). P. 380-385. DOI: 10.1089/cyber.2015.0055

Islam MA, Barna SD, Raihan H, Khan MNA, Hossain MT. Depression and anxiety among university students during the COVID-19 pandemic in Bangladesh: A web-based cross-sectional survey. PLOS ONE. 2020. 15(8): e0238162. DOI: 10.1371/journal. pone.0238162

Ivie, E. J., Pettitt, A., Moses, L. J., \& Allen, N. B. A meta-analysis of the association between adolescent social media use and depressive symptoms. Journal of Affective Disorders. 2020. No. 275. P. 165-174. DOI: $10.1016 /$ j.jad.2020.06.014

Khmiliar, O., Popovych, I., Hrys, A., Pavliuk, M., Zavatska, N., Lytvynenko, O., \& Blynova, O. Spatial Regulation of Personality Behavior in the Conditions of Progression of the COVID-19 Pandemic. Revista Inclusiones, 2020. Vol: 7 num Especial. P. 289-306. URL: http://www.revistainclusiones. org/index.php/inclu/article/view/1760

Ma Feng, Shevchenko, R. P. \& Karhina N. V. Student youth representation of psychological well-being: results of content analysis of works. Insight: the psychological dimensions of society, 2020. 3. P. 44-55. DOI: 10.32999/2663-970X/2020-3-3

Primack, B. A., Shensa, A., Sidani, J. E., Whaite, E. O., Lin, L. Y., Rosen, D., Colditz, J. B., Radovic, A., \& Miller, E. Social Media Use and Perceived Social Isolation Among Young Adults in the U.S. American

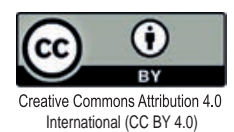


Psychological well-being and social media users' behavioral online patterns in everyday life and during COVID-19 pandemic

Journal of adolescence, 79, 258-274. https://doi. org/10.1016/j.adolescence.2020.01.014

Verduyn, P., Ybarra, O., Résibois, M., Jonides, J. and Kross, E. (2017), Do Social Network Sites Enhance or Undermine Subjective Well-Being? A Critical Review. Social Issues and Policy Review, 11: 274-302. https://doi.org/10.1111/sipr.12033

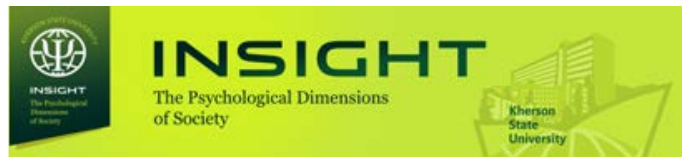

journal of preventive medicine. 2017. 53(1). 1-8. DOI: 10.1016/j.amepre.2017.01.010

Saiphoo, A. N., \& Vahedi, Z. A meta-analytic review of the relationship between social media use and body image disturbance. Computers in Human Behavior. 2019. No. 101. P. 259-275. DOI: 10.1016/j.chb.2019.07.028

Seabrook, E. M., Kern, M. L., \& Rickard, N. S. Social networking sites, depression, and anxiety: a systematic review. JMIR mental health. 2016. 3(4). e5842.

Shakya, H. B., \& Christakis, N. A. Association of Facebook Use With Compromised Well-Being: A Longitudinal Study. American journal of epidemiology. 2017. 185(3). 203-211. DOI: 10.1093/aje/kww189

Tennant, R., Hiller, L., Fishwick, R., Platt, S., Joseph, S., Weich, S., Parkinson, J., Secker, J., \& Stewart-Brown, S. The Warwick-Edinburgh Mental Well-being Scale (WEMWBS): Development and UK validation. Health and Quality of Life Outcomes. 2007. No. 5. Article 63. DOI: 10.1186/1477-7525-5-63

Vannucci, A., Simpson, E. G., Gagnon, S., \& Ohannessian, C. M. Social media use and risky behaviors in adolescents: A meta-analysis. Journal of Adolescence . 2020. P. 258-274. DOI: 1016/j.adolescence.2020.01.014

Verduyn, P., Ybarra, O., Résibois, M., Jonides, J., \& Kross, E. Do Social Network Sites Enhance or Undermine Subjective Well-Being? A Critical Review. Social Issues and Policy Review. 2017. No. 11(1). P. 274-302. DOI:10.1111/sipr.12033. 